\title{
GENDER EQUALITY IS ONE OF THE REQUIREMENTS OF A DEVELOPED SOCIETY
}

\author{
Nilufar Djuraeva Dalibaevna \\ Uzbek State University Of World Languages, Uzbekistan
}

\section{ABSTRACT}

The article scientifically analyzes that gender - relations between men and women - is a social phenomenon in all spheres of life and activities of society, that is, it means social equality in gender relations. It was also emphasized that one of the requirements of a developed society is to ensure equal rights for men and women. After all, this balance in society is the key to sustainable development and a prosperous future for humanity. Therefore, this value has always enjoyed great respect in the history of human society.

KEYWORDS: - gender, gender relations, equality, society, state, politics, economics, education, science, social equality, interaction, development factor.

\section{INTRODUCTION}

Gender is an important social aspect of the relationship between women and men that manifests itself in all spheres of life and activity in society, including politics, economics, law, ideology and culture, education and science. In this sense, the concept of gender not only represents the interests of women, but also the need for both sexes to take a bold step towards their dreams and goals, to provide equal opportunities to improve the quality of life. One of the requirements of a developed society is to ensure equality between men and women. After all, this balance in society is a guarantee of sustainable development and a prosperous future of mankind. Therefore, this value has always been highly respected in the history of human society.

\section{Methods}

The article presents the data studied on the basis of generally accepted methods of analysis. It is also scientifically analyzed that during the years of independence, the protection of the rights and interests of women has risen to the level of public policy and strategy. Describes the content and essence of normative legal acts adopted in the field of gender equality.

\section{RESEARCH RESULTS}

Indeed, ancient Greek scholars such as Socrates, Aristotle, and Plato referred to the police as the best state in which equality and justice reigned in society. They also put forward laws that guaranteed all equality as the best laws. The Greek scholar Antifont used the idea of equality between men and women in his works: "Nature creates everyone: women and men equally, but people develop laws that make people unequal." In 1791, the Declaration of Civil and Women's Rights, drafted by Olympia De Guj, recognized for 
CURRENT RESEARCH JOURNAL OF HISTORY 2(6): 82-85, June 2021

DOI: https://doi.org/10.37547/history-crjh-02-06-18

ISSN 2767-472X

(C)2021 Master Journals

\section{Crossref dof 80 Google}

Accepted 25th June, 2021 \& Published 30 3 June, 2021

the first time that women had the right to think and express themselves freely. If we pay attention to the legal development of gender equality, first of all, it is necessary to analyze the historical-theoretical and legal aspects of the legal basis of gender equality in international and national legislation. Of course, we all know that the Universal Declaration of Human Rights, adopted by the UN General Assembly in 1948, recognizes the equality of men and women, and Article 1 of the Declaration states: They are endowed with reason and conscience, and therefore should treat each other in the spirit of brotherhood. " Another international instrument adopted by the United Nations in 1966, Article 3 of the International Covenant on Civil and Political Rights, states that "States Parties undertake to ensure that men and women have equal access to all civil and political rights provided for in this Covenant." Article 2 of the Law "On Guarantees of Equal Rights and Opportunities for Women and Men" states that the legislation on guarantees of equal rights and opportunities for women and men consists of this Law and other legislative acts. legal basis. Therefore, it is reasonable that our independent state, which has ratified the above-mentioned international documents, attaches great importance to the issue of equality of women and men in its national legislation, based on the universally recognized requirements of international law.

Another legal guarantee of this basis is that Article 46 of the Constitution of the Republic of Uzbekistan states that "women and men have equal rights." This means that both international legal and constitutional legal basis for gender equality is guaranteed. Gender equality also means social equality. It is not enough to include the necessary provisions in the Constitution and laws to ensure such equality. Therefore, special attention is paid to "raising the legal culture in society."
The development and adoption of a strategy for gender equality in Uzbekistan will help to build respect for human rights in the country and further enhance the image of Uzbekistan in the international arena. For the first time in the history of Uzbekistan, the number of women in the national parliament has reached the level set by the UN. According to this indicator, our country is in the top 50

In recent years, work has been done to ensure gender equality and increase the role of women in social and political life in several areas:

- Improving women's rights legislation;

- Improving the institutional framework for women's protection;

- Raising public awareness of gender equality and women's rights;

- Training of officials responsible for ensuring compliance with law enforcement practices in accordance with relevant legal standards.

Over the past four years, our country has adopted two laws on gender equality, support for women, increasing their role in government and society, 6 decrees and resolutions of the President, 16 government decrees.

Gender equality is a noble value that plays an important role not only in ensuring human rights, but also in the political, socio-economic development of society. In addition, gender equality is one of the indicators of a country's level of democratic development. Therefore, in today's era of globalization, this issue is a priority in society.

In particular, the Law of the Republic of Uzbekistan "On guarantees of equal rights and opportunities for women and men", adopted on September 2, 2019, is a comprehensive and fundamental piece of legislation aimed at ensuring gender equality in our country. With this law, for the first time in our national 
CURRENT RESEARCH JOURNAL OF HISTORY 2(6): 82-85, June 2021

DOI: https://doi.org/10.37547/history-crjh-02-06-18

ISSN 2767-472X

(C)2021 Master Journals

\section{Crossref dof 80 Google}

Accepted 25th June, 2021 \& Published 30 3 June, 2021

legislation, the concept of "gender" is defined. The law defines the main directions of state policy in the field of ensuring equal rights and opportunities for women and men, the mechanisms of public administration in this area. In particular, in order to prevent gender discrimination against women, the Commission on Gender Equality was established in the Republic of Uzbekistan.

An advisory council on gender equality has been set up in ministries and departments. The "Strategy for Achieving Gender Equality in the Republic of Uzbekistan in 2020-2030" aimed at ensuring equal rights and opportunities for women and men in the political, social and economic spheres was adopted. The implementation of the gender strategy will contribute to the implementation of national and international commitments, the Beijing Declaration and Action Plan, the Convention on the Elimination of All Forms of Discrimination against Women, the Sustainable Development Goals and others.

In recent years, special attention has been paid to ensuring equal rights for women and men, increasing the role of women in public administration, and appointing women to various positions of responsibility. As a result, our women hold responsible positions such as deputies, senators, governors, ambassadors, prosecutors, judges, and tax collectors.

In order to further increase the participation of women in public administration, a reserve of more than 6,000 active women has been formed. At present, systematic trainings are being organized to prepare them for various leadership positions.

Currently, a number of ministries and agencies have an Advisory Council on Gender Equality. Often, members of this council are faced with the question of who should lead this council, how to organize work in this direction. In order to provide them with methodological and practical assistance in this area, we want to develop a media plan and strengthen advocacy. The purpose of the national contest "Gender Equality Activist" is to analyze and promote the work done in this area, to disseminate best practices, to protect the rights and interests of women, to increase their participation in society. According to the results of each year, the competition is traditionally held in the field of gender equality, which promotes the development of society, the protection of women's rights, the implementation of relevant tasks in their respective fields. and journalists will participate. The competition will be held in several main nominations. In short, the issue of gender equality has been raised as a priority in our society today. Extensive legal and practical work has been launched in this regard. Most importantly, the results of these measures are showing their effectiveness in the short term in ensuring the strength of the family and stabilizing the spiritual and educational environment in society. In the future, this noble work will be continued and will rise to a new level.

The share of women in political parties has increased to $44 \%$, in higher education to $40 \%$, in entrepreneurship to $35 \%$, and women are widely involved in information and communication, innovation, energy, and engineering.

"The share of women in management positions has reached 27 per cent. More than 15,000 people, including advanced and educated women, have been formed in 81 ministries and departments, "the senator said.

For the development of women's entrepreneurship, more than 224,000 women received soft loans totaling 6.9 trillion soums, the People's Bank was attached to them, and Women's Entrepreneurship Centers were established in 14 regions. The system of 
rehabilitation and adaptation of victims of violence has been radically revised.

The Strategy for Gender Equality in Uzbekistan until 2030 envisages a comprehensive approach to the implementation of the principle of equality between women and men in all areas and levels of decision-making and implementation. The Strategy also serves to create conditions for the realization of equal rights and opportunities for men and women and to promote gender equality in economic, political and social life in order to respect fundamental human rights.

The strategy covers issues such as providing equal and quality education for all, higher education for girls in rural areas, gender equality for women, prevention of violence, and prevention of human trafficking.

Through the implementation of the gender strategy, the following will be achieved:

Expands the practice of appointing women to senior positions in government bodies at the top and bottom.

Equilibrium between women and men will be ensured through the introduction of a temporary quota system in public bodies where gender disparities exist.

Families in need and low-income, especially in rural areas, are provided with employment, creation of decent working conditions and social support, as well as self-employment.

The most important thing is to prevent cases of harassment and violence against women in the workplace and to eliminate the negative attitudes towards them in society.

\section{ReFERENCES}

1. Decree PF-4947-conli "On the Strategy of further development of the Republic of Uzbekistan" dated February 7, 2017, PF-
February 2, 2018 "On measures to radically improve the activities in the field of support of women and strengthening the institution of the family" Decree No. 5325, Presidential Decree PQ-4235 of March 7, 2019 "On measures to further strengthen the guarantees of women's labor rights and support entrepreneurship", Decree of September 2, 2019 "On measures to further strengthen the guarantees of women's labor rights and support entrepreneurship" Law No. ZRU 561 "On protection from violence" and ZRU 562 "On guarantees of equal rights and opportunities for women and men" // lex.uz

2. Uzbekistan is taking important steps to ensure gender equality // https://strategy.uz/index.php?news=745

3. Khidirova B. The strategy for achieving gender equality is based on national and universal values // https://yuz.uz/news/gender-equalitystrategy-is-national-and-human-dignities

4. The Senate adopted a strategy for achieving gender equality by $2030 / /$ https: //www.google.com/url? 